\title{
Development of the High-purity Aluminium Oxide Powder Producing Technology on the Ural Region Raw Materials Basis
}

\author{
I.D. Kashcheev¹, K.G. Zemlyanoy¹, A.V. Doronin², and K.O. Stepanova1 \\ 1 Ural Federal University, Ekaterinburg, Sverdlovsk region, Russia \\ ${ }^{2}$ HYDROCHROM LLC, Ekaterinburg, Sverdlovsk region, Russia
}

\section{Abstract}

This article considers an effective way of complex alumina-containing materials of natural or technogenic origin processing with obtaining a whole complex of raw materials: alkali-free highly active aluminum hydroxide, iron hydroxide, aluminum hydroxide, etc. In laboratory conditions the alumina raw materials behavior in the thickening, washing, filtration processes were checked. The optimal parameters of the processes were selected as a result of conducted research.

Corresponding Author:

K.G. Zemlyanoy

kir77766617@yandex.ru

Published: 31 December 2020

Publishing services provided by

Knowledge E

(c) I.D. Kashcheev et al. This article is distributed under the terms of the Creative Commons Attribution License, which permits unrestricted use and redistribution provided that the original author and source are credited.

Selection and Peer-review under the responsibility of the TECHNOGEN-2019 Conference Committee.

\section{G OPEN ACCESS}

In modern conditions, the implementation of the concept of "innovation for economic development - IFED" is increasingly associated with the problems of complex waste-free natural resources processing and the involvement of multi-tonnage industrial waste in environmentally friendly, waste-free innovative technology.

The amount of industrial wastes for the last hundred years grows exponentially. In the world more than 25 billion tons of solid industrial waste is formed annually. Almost one third of this amount - more than 7 billion tons - is accounted for Russia. As of the beginning of 2013 , more than 90 billion tons of production and consumption waste have been accumulated on the territory of the Russian Federation. The area occupied by organized waste disposal sites amounted to more than 400 thousand hectares.

One of the promising areas of the innovation process is the complete industrial waste processing within the regional economic complexes framework. It includes extraction of scarce materials (pure oxides, noble, nonferrous, rare, radioactive and other elements) from industrial wastes and creation of structural and functional materials with high operational properties instead of natural, traditional materials and metals. The implementation of this strategy will allow to significantly reduce the consumption of primary natural 
resources by more than $25 \%$, as well as to solve the issues of raw material security of the country, including the materials critical for the ceramic electronic, electrical and metallurgical industries - high alumina and magnesium.

This work is devoted to important technological issues of technogenic and natural alumina raw materials complex use for the purpose of valuable components extraction, while solving environmental problems.

The authors have tested the technology of complex processing of industrial and/or natural aluminosilicate materials production wastes with the use of recoverable leaching sulphuric acid solution - ammonium hydrosulfate solution. The technology includes:

1) Sulphuric acid leaching of raw materials with ammonium hydrosulphate solution with extraction of iron III and aluminum into the solution by the following reactions:

$2 \mathrm{AlOOH}+6 \mathrm{NH}_{4} \mathrm{HSO}_{4}=\mathrm{Al}_{2}\left(\mathrm{SO}_{4}\right)_{3}+3\left(\mathrm{NH}_{4}\right)_{2} \mathrm{SO}_{4}+4 \mathrm{H}_{2} \mathrm{O}$

$\mathrm{Fe}_{2} \mathrm{O}_{3}+6 \mathrm{NH}_{4} \mathrm{HSO}_{4}=\mathrm{Fe}_{2}\left(\mathrm{SO}_{4}\right)_{3}+3\left(\mathrm{NH}_{4}\right)_{2} \mathrm{SO}_{4}+3 \mathrm{H}_{2} \mathrm{O}$;

2) Filtration of acid-resistant residue containing $\mathrm{RO}_{2}, \mathrm{R}_{2} \mathrm{O}_{5}$ oxides for subsequent use as raw materials for the production of building materials, refractories, ceramics, abrasives, etc;

3) Iron III deposition from ammonia solution and separation of iron hydroxide III for further use in the production of pigments;

$$
\mathrm{Fe}_{2}\left(\mathrm{SO}_{4}\right)_{3}+6 \mathrm{NH}_{4} \mathrm{OH}=2 \mathrm{Fe}(\mathrm{OH})_{3} \downarrow+3\left(\mathrm{NH}_{4}\right)_{2} \mathrm{SO}_{4} \text {; }
$$

4) Aluminium precipitation from ammonia solution and separation of aluminium hydroxide for further use as a raw material;

$\mathrm{Al}_{2}\left(\mathrm{SO}_{4}\right)_{3}+6 \mathrm{NH}_{4} \mathrm{OH}=2 \mathrm{Al}(\mathrm{OH})_{3} \downarrow+3\left(\mathrm{NH}_{4}\right)_{2} \mathrm{SO}_{4}$;

5) Obtaining a pure solution of ammonium sulfate from which crystalline ammonium sulfate is extracted; according to the technology developed and tested at the pilot plant, it is thermally decomposed into ammonium hydrosulfate and ammonia by reaction:

$\left(\mathrm{NH}_{4}\right)_{2} \mathrm{SO}_{4}=\mathrm{NH}_{4} \mathrm{HSO}_{4}+\mathrm{NH}_{3} \uparrow$.

6) Return of the obtained ammonium sulfate and ammonia into production.

The raw materials for the study were selected as kaolin waste from the Zhuravlinny Log deposit (Plast, Chelyabinsk Region) and Poletaevskoye deposit (Chelyabinsk) as raw kaolin. Phase composition of initial materials includes, wt. \%: kaolinite $\mathrm{Al}_{4}\left[\mathrm{Si}_{4} \mathrm{O}_{10}\right](\mathrm{OH})_{8}$ - 95,0-97,0; quartz $\mathrm{SiO}_{2}$ - 1,0-2,0 and feldspars (microcline $\mathrm{K}, \mathrm{Na}\left(\mathrm{AlSi}_{3} \mathrm{O}_{8}\right)$ ) - 1,0 - 3,0.

The offered technology of hydrochemical processing, allowing to improve opening of initial raw materials and to increase the target product yield, consists of:

Preliminary grinding of raw materials up to the full passage through the sieve 0,08 $\mathrm{mm}$; 
Preparation of $\mathrm{H}_{2} \mathrm{SO}_{4}$ technical solution with content: 10, 15 и $20 \%$;

Pelletizing of ground raw materials with addition of $\mathrm{H}_{2} \mathrm{SO}_{4}$ solution;

Classification of the obtained granules with the separation of the fraction of 3-7 mm and the return of the remaining fractions to the stage of granulation.

Heat treatment of the obtained granules at a temperature of $350-600^{\circ} \mathrm{C}$.

Phase composition of granulated products after heat treatment at 350 (and 600 ) ${ }^{\circ} \mathrm{C}$ is presented, wt. \%: metakaolinite $\mathrm{Al}_{2} \mathrm{O}_{3} \cdot 2 \mathrm{SiO}_{2}-85,0-94,0$ (14,0-66,0); quartz $\mathrm{SiO}_{2}$ - 1,02,0 (13,0-33,0); hydroslides $\mathrm{Na}, \mathrm{K}, \mathrm{Al}_{2}\left[\mathrm{AlSi}_{3} \mathrm{O}_{10}\right](\mathrm{OH})_{2}-3,0-14,0(43,0-58,0)$ and aluminum sulfate $0,0-2,0(15,0-23,0)$. It has been established that in the process of heat treatment the materials granulated with $20 \%$ sulphuric acid solution and heat-treated at the temperature of not less than $500{ }^{\circ} \mathrm{C}$ are subject to the greatest change; at the same time the products have a latent-crystalline, almost amorphous structure of metakaolinite $\mathrm{Al}_{2} \mathrm{O}_{3} \cdot 2 \mathrm{SiO}_{2}$. The leaching process of the target products is based on the reaction:

$$
\mathrm{Al}_{2} \mathrm{O}_{3} 2 \mathrm{SiO}_{2}+3 \mathrm{H}_{2} \mathrm{SO}_{4}=\mathrm{Al}_{2}\left(\mathrm{SO}_{4}\right)_{3}+2 \mathrm{SiO}_{2}+\mathrm{H}_{2} \mathrm{O}
$$

in slow boiling mode (5-7 $\mathrm{min}$ ) and natural cooling of the solution (50-60 min) with further decantation and washing of the sludge. Wash water is collected and directed to obtaining a leaching solution. The results of the leaching process are presented in Table 1.

TABLE 1: Leaching process results

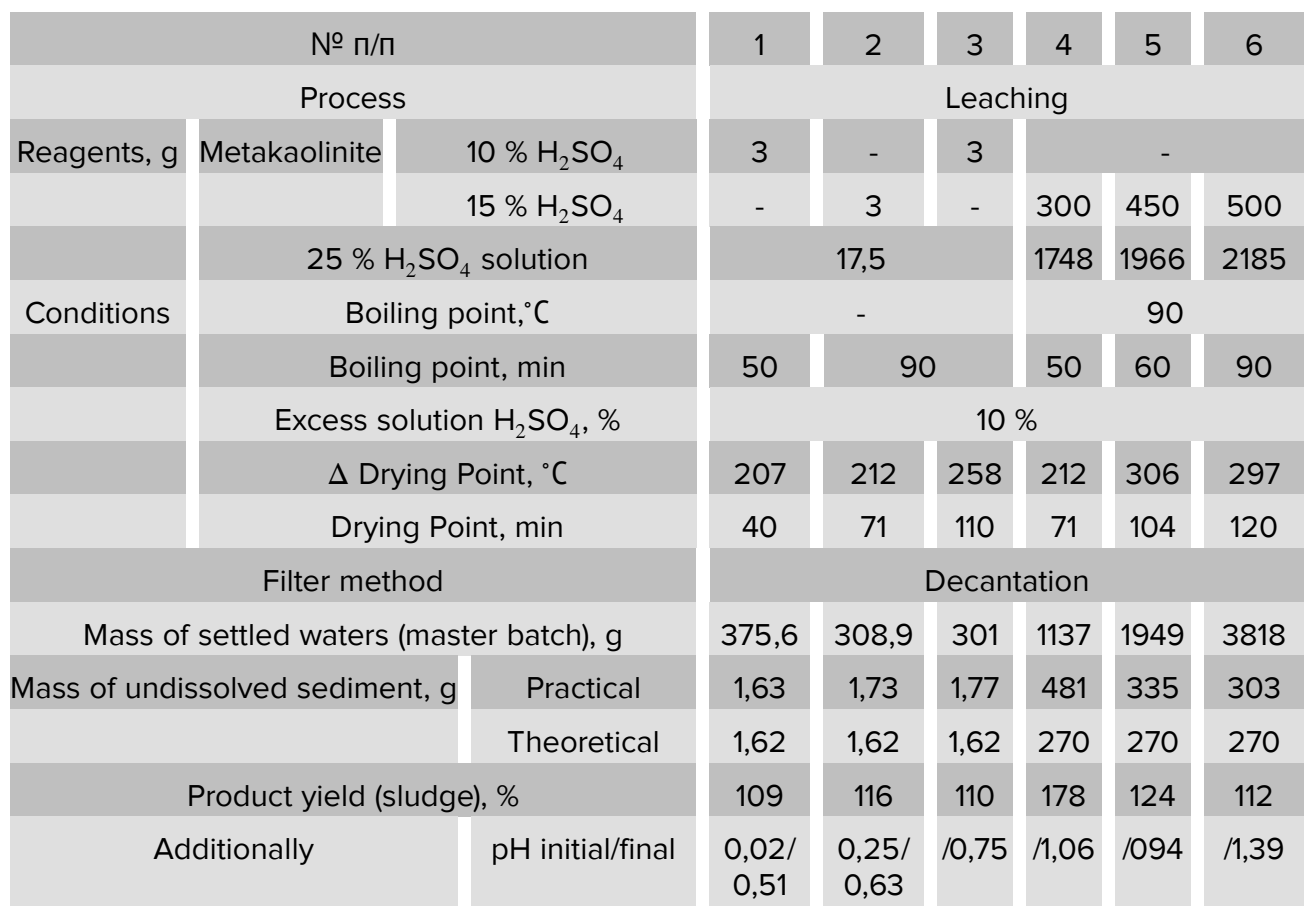

Based on the results of leaching, it can be concluded that the best way to achieve leaching is to use $15 \% \mathrm{H}_{2} \mathrm{SO}_{4}$ as the leaching agent. 
The process of deposition of aluminum sulphate solution purified from iron oxides was performed at the temperature of solution $20-60{ }^{\circ} \mathrm{C}$ by step-by-step introduction of solution $\mathrm{NH} 4 \mathrm{OH}$ in the ratio 1: 2 with $\mathrm{pH}$ control of the solution every 5-10 minutes to the final $\mathrm{pH}$ of the solution 4,0 - Table 2. After sedimentation the sludge settling, decantation and washing is performed. Drying and thermal treatment of hydroxide was carried out in laboratory furnaces at the temperature of $400-550{ }^{\circ} \mathrm{C}$ until the mass loss was stopped. The obtained product contains, wt. \%: $\mathrm{Al}_{2} \mathrm{O}_{3}-99,2 ; \mathrm{R}_{2} \mathrm{O}-0,14 ; \mathrm{RO}$ 0,$01 ; \mathrm{Fe}_{2} \mathrm{O}_{3}-0,05 ; \mathrm{SiO}_{2}-0,08$. The specific surface of the material was $5680 \mathrm{~m}^{2} / \mathrm{g}$, the average particle size was $2.7 \mu \mathrm{m}$.

TABLE 2: Precipitation results

\begin{tabular}{|c|c|c|c|c|c|c|c|c|}
\hline № $ா / \sqcap$ & 1 & 2 & 3 & 4 & 5 & 6 & 7 & 8 \\
\hline $\mathrm{Al}_{2}\left(\mathrm{SO}_{4}\right)_{3}$ solution & 588 & 250 & 500 & 500 & \multicolumn{4}{|c|}{100} \\
\hline $\mathrm{NH}_{4} \mathrm{OH}$ solution & - & 146 & 268 & 278 & 431 & 548 & 915 & 670 \\
\hline $10 \%$ solution of $\mathrm{NH}_{4} \mathrm{NaSO}_{3}$ & 520 & 520 & 1040 & 1210 & 2420 & 2420 & 1815 & 1815 \\
\hline Excess $10 \%$ solution of $\mathrm{NH}_{4} \mathrm{NaSO}_{3}$ & \multicolumn{3}{|c|}{1,5} & \multicolumn{3}{|c|}{2} & \multicolumn{2}{|c|}{1,5} \\
\hline Boiling point, ${ }^{\circ} \mathrm{C}$ & \multicolumn{6}{|c|}{82} & \multicolumn{2}{|c|}{74} \\
\hline Boiling point, min & \multicolumn{8}{|c|}{120} \\
\hline$\Delta$ Drying Point, ${ }^{\circ} \mathrm{C}$ & $\begin{array}{l}127- \\
278\end{array}$ & $\begin{array}{l}162- \\
347\end{array}$ & $\begin{array}{l}166- \\
296\end{array}$ & $\begin{array}{l}204- \\
343\end{array}$ & $\begin{array}{l}194- \\
289\end{array}$ & $\begin{array}{l}193- \\
320\end{array}$ & $\begin{array}{l}201- \\
315\end{array}$ & $\begin{array}{r}199- \\
321\end{array}$ \\
\hline Drying Point, min & 124 & 235 & 189 & 180 & 199 & 201 & 200 & 198 \\
\hline Filter method & \multicolumn{8}{|c|}{ Decantation } \\
\hline Product & \multicolumn{8}{|c|}{$\mathrm{Al}(\mathrm{OH})_{3}$} \\
\hline Undissolved sediment mass (master batch), g & - & 680 & - & - & - & - & - & - \\
\hline Sludge mass actual, g & 14 & 13 & 33 & 41 & 38 & 140 & & \\
\hline Sludge mass theoretical, $\mathrm{g}$ & 13 & 13 & 26 & 26 & 26 & 52 & & \\
\hline Product yield, \% & 108 & 100 & 127 & 158 & 146 & 269 & & \\
\hline $\mathrm{pH}$ after adding technical ammonia & - & 4,15 & 4 & - & - & - & - & 3,7 \\
\hline $\mathrm{pH}$ master batch & - & 5,66 & - & - & - & - & 4,01 & - \\
\hline
\end{tabular}

\section{Conclusions}

The possibility of developing a technology based on the raw materials of the Ural deposits using metakaolinite to produce pure aluminium oxide and other products from aluminium sulphate, which will make it possible to create an energy- and resourceefficient technology to produce high-purity $\mathrm{Al}_{2} \mathrm{O}_{3}$ powders with high level of physical and mechanical properties, was demonstrated. 


\section{References}

[1] Panov, D.S. and Loginova, I.V. (2009). Study of the complex red sludge processing with the scandium concentrate separation (in Russian). Nasledie, V.I. Vernadsky, vol. 9, p.253.

[2] Raspopov, D.S., et al. (2013). Iron oxide recovery during pyrometallurgical red mud processing (in Russian). Metals. vol. 1, pp.41- 45.

[3] Budon, S.V., et al. (2013). Hydrochemical processing of red muds of JSC "ALYUMINIY KAZAKHSTAN" (in Russian). Notes of the Mining Institute, vol. 202, pp. 44-47.

[4] Utkov, V.A., et al. (2013). Joint integrated bauxite and red mud processing (in Russian). Nonferrous metals. no. 12 (852), pp.36-39.

[5] Garshin, A.P., et al. (2003) Ceramics for mechanical engineering (in Russian). M.: OOO Publishing house "Nauchtehlitizdat". 384 p.

[6] Pavushkin, N.M. (1961). Sintered Corundum (in Russian). Moscow: Stroyizdat. - 200 p.

[7] GOST 30558-98. (2002). Metallurgical alumina. Specifications. PKI Publishing house of standards.

[8] Balkevich, V.L. (1968). Technical Ceramics (in Russian). Moscow: Publishing house of construction literature. $-208 \mathrm{p}$.

[9] Belinskaya, G.V. and Vydrik, G.A. (1977). Electric vacuum and Radio-technical ceramics: A textbook for radio-technical specialties of technical schools (in Russian). Moscow: Energy. - 336 p.

[10] Amelina, O.D. and Nesterov, S.B. (2007). Besspektivaya tekhnologii vakuumplotnoi korundovoi ceramiki VK100-2. (in Russian). Vacuum engineering and technology: Abstracts of the Third Russian student scientific and technical conference Kazan, KSTU. 10-12.04.2007.// - Kazan: KSTU publishing house - $159 \mathrm{p}$. 